\title{
Liveweight production of ewes and lambs grazing a dryland lucerne monoculture with or without barley grain supplementation
}

\author{
D.J. MOOT, A.M. MILLS, M.M. ROUX and M.C. SMITH \\ Field Research Centre, PO Box 85084, Lincoln University, New Zealand
}

Derrick.Moot@lincoln.ac.nz

\begin{abstract}
In 2013/2014 (Year 1) and 2014/2015 (Year 2) at Ashley Dene, Canterbury, New Zealand, sheep grazing dryland lucerne monocultures were supplemented with barley grain. In neither year did barley grain supplementation improve lamb growth rates. In 2013/2014 total liveweight (LWt) production of lambs was $782 \pm 11.5 \mathrm{~kg}$ LWt /ha between 3/9/2014 and 3/2/2015 when pastures were destocked. However, ewes with continuous access to barley grain gained $12.4 \mathrm{~kg} \mathrm{LWt} / \mathrm{ha}$ over the lactation period compared with those without access to grain that lost $14.0 \mathrm{~kg} \mathrm{LWt} / \mathrm{ha}$. In 2014/2015 (Year 2), liveweight production of lambs totalled $408 \pm 1.0 \mathrm{~kg} \mathrm{LWt} / \mathrm{ha}$ from those with no access to grain and $382 \pm 1.0 \mathrm{~kg} \mathrm{LWt} /$ ha from those with grain supplementation. Upon restocking with weaned lambs, each lamb with access to grain gained $154 \pm 9.8 \mathrm{~g} / \mathrm{d}$ which was less than those without grain access $(188 \pm 9.7 \mathrm{~g} / \mathrm{d})$. Sheep ingested $25-83 \mathrm{~g} / \mathrm{d}$ of grain with $a d$ lib feeding. These results support previous literature that suggests liveweight responses from grain supplementation of sheep are inconsistent.
\end{abstract}

Keywords: alfalfa, Medicago sativa, Hordeum vulgare, feed conversion efficiency

\section{Introduction}

Recent farmer interest in grain supplementation provided to stock grazing lucerne pastures was the basis for the current experiment. The idea was that high protein diets may have an energy imbalance which can result in low rumen efficiency and protein utilisation (Dixon \& Stockdale 1999; Schroeder \& Titgemeyer 2008). Supplying barley grain as a supplement may redress the protein:energy imbalance (Broderick 2001) and increase protein utilisation. Sheep have a lower retention time of feed in the rumen compared with cattle (Cannas 2004; Cannas \& Van Soest 2000; Van Soest 1994) and the low fibre content of lush lucerne impacts on rumination, protein synthesis and the amount of protein which escapes rumen degradation.

Most research on grain supplementation has focussed on dairy cattle and animals in feedlots, with low quality conserved forage supplemented with grain (Doyle et al. 1988). Research that focusses on supplementation of livestock grazing high quality feed sources, such as lucerne, is scarce and, regardless of stock class, results have been inconsistent (Karnezos et al. 1994; Klee et al. 2011; Wolfe et al. 1980). This research investigated liveweight gain of ewes and lambs grazing monocultures of lucerne with or without access to barley grain over 2 years.

\section{Materials and methods Experimental}

At Ashley Dene farm in Canterbury, New Zealand, an existing experiment had a barley supplementation treatment superimposed on the lucerne monocultures. Each of the six lucerne paddocks were randomly split in half. Stock grazing one half were provided with barley grain (+Grain) while the other half only had the standing lucerne (-Grain). In Year 1, grazing began on $3 / 9 / 2013$ by ewes with twin lambs at foot. Plots were fully stocked by 18/9/2013 and rotational grazing began shortly after. In this year whole barley grain was available in a grain feeder. In Year 2 (2014/2015) grazing was initiated on 18/9/2014 and treatments were fully stocked by $30 / 9 / 2014$. In Year 2 only crushed barley grain was available from the supplier, so this was used.

\section{Grain feeding}

An 'Advantage Feeder (NGF 800)' supplied barley to the + Grain mob from 13/9/2013 in Year 1. In Year 2, barley was made available from Day 1 (18/9/2014). Grain intake from the feeder was marketed as being restricted to 5 minute intervals because only the tongue can reach the grain and the inability to produce sufficient saliva restricts longer periods at the feeder (Advantage Feeders Ltd 2013). No limits were made to the number of visits an animal made to the dispenser during the day. To replicate commercial farms, ewes were not trained on using the feeder. They were given ad lib access until 14 October each year to train lambs to use the feeder and were then deliberately excluded by fitting an adjuster guard. This fitting was ineffective in 2013/2014 and ewes accessed grain until weaning. In $2014 / 2015$ no restriction was placed on the daily grain allowance until the guard was fitted.

The feeder was topped up with $36-44 \mathrm{~kg}$ grain on 16 dates in Year 1 and on 5 dates in Year $2(20 \mathrm{~kg}$ grain each time). The amount of grain remaining in the 


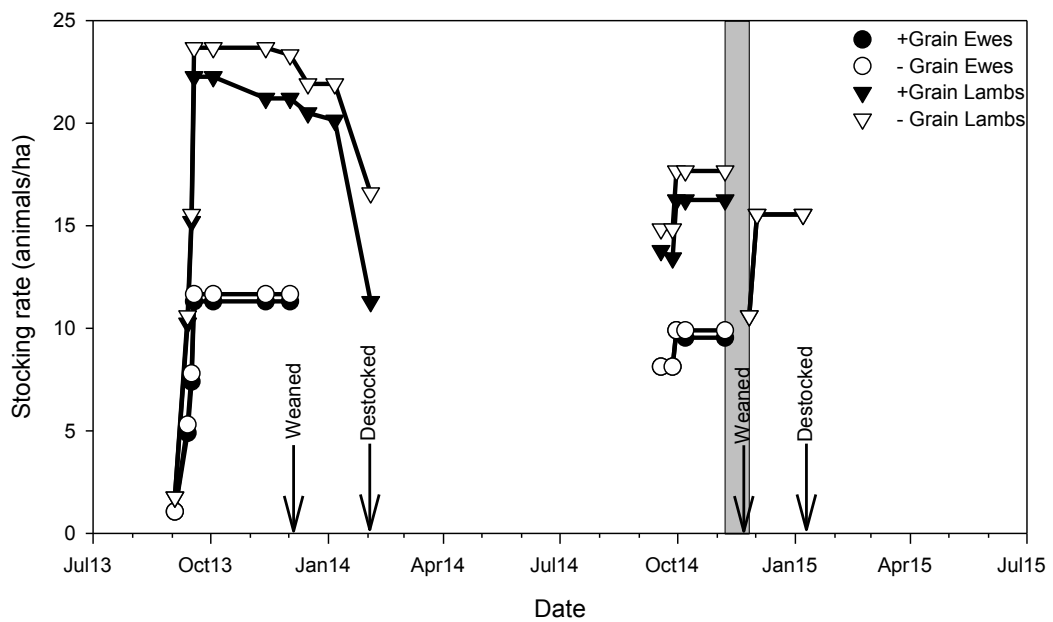

Figure 1 Stocking rate of ewes and lambs in 2013/2014 and 2014/2015 grazing lucerne monocultures with (+Grain, black fill) or without (-Grain, white fill) barley grain supplementation. The grey area shows when pastures were destocked due to lack of feed supply.

feeder was visually estimated on 2/12/2013 (weaning) or at destocking (7/11/2014). In 2013/2014 a total of $619 \mathrm{~kg}$ of whole barley grain was ingested by ewes and lambs in the lactation phase (13/9/2013-2/12/2013; 80 days). The daily average ingestion per sheep of the 32 ewes and 61 lambs at foot was $83 \mathrm{~g} /$ day. Post-weaning, lambs were returned to the lucerne for 34 days from $17 / 12 / 2013$. A total of $127 \mathrm{~kg}$ of grain was ingested ad lib by weaned lambs at $46-79 \mathrm{~g} / \mathrm{d}$ per sheep. The grain feeder was never empty when topped up. In 2014/2015, $95 \mathrm{~kg}$ of crushed barley grain was ingested from 18/9/2014 to $7 / 11 / 2014$. The estimated ingestion per sheep was $31.4 \mathrm{~g}$ crushed barley grain/day for this period. Weaned lambs grazed for a further 37 days from $7 / 1 / 2014$ and ingested an average per sheep of $25 \mathrm{~g}$ barley/day per sheep.

\section{Environmental conditions}

The long-term mean rainfall at the Burham sewage treatment plant, $\sim 5 \mathrm{~km} \mathrm{NE}$ of the experiment, was 640 $\mathrm{mm} / \mathrm{yr}$. In 2013/2014 rainfall was $710 \mathrm{~mm} /$ year and $422 \mathrm{~mm} /$ year fell in 2014/2015 which effectively gave a 'wet' and a 'dry' year for evaluation.

\section{Dry matter yields}

Dry matter yields were estimated pre- and post-grazing from a relationship between total yield and lucerne height $(\mathrm{cm})$. Three destructive $0.2 \mathrm{~m}^{2}$ quadrat cuts were taken from three plots where grain was unavailable and another three where grain was available, each rotation, until grain feeding was terminated. Linear regressions were fitted in Genstat (v16; VSN International Ltd). In 2013/2014 the regression for pre-graze yield was Yield $=-200(174)+106.4(7.9) x\left(\mathrm{R}^{2}=0.88\right)$, where ' $x$ ' refers to lucerne height. The post-graze height and yield relationship differed and was Yield $=160.3(82.8)+$ $55.6(4.58) x\left(\mathrm{R}^{2}=0.80\right)$. For $2014 / 2015$, the equation was Yield $=82.6(2.60) x\left(\mathrm{R}^{2}\right.$ $=0.80$ ).

\section{Analysis}

In Year 1, ewes and lambs were weighed three times during lactation and three times post-weaning. In the drier Year 2, liveweights were recorded twice in the lactation phase and once in the post-weaning period. Liveweight production $(\mathrm{kg} / \mathrm{ha})$ was determined from the seasonal weighted liveweight gains for each stock class and the number of grazing days on each of the six paddocks, generating a replicated data set. Dry matter $(\mathrm{kg} / \mathrm{ha})$ and liveweight production data were analysed by ANOVA. Where appropriate means were separated by Fishers protected LSD at $\alpha=0.05$.

\section{Results}

\section{Stocking rate}

Average stocking rates of ewes with lambs at foot are shown in Figure 1. In spring 2013, the -Grain mob had $\sim 3.5 \%$ more ewes and $6-12 \%$ more lambs because all single bearing ewes were randomly allocated to the + Grain treatment. Stocking rates varied more after weaning because lambs were drafted out of their mob at target liveweights. The-Grain group were stocked with 16.6 lambs/ha on 3/2/2012 compared with 11.3 lambs/ ha in the +Grain group. In spring 2014, there were 9.5 ewes and $16.3 \mathrm{lambs} / \mathrm{ha}$ on the +Grain treatment, and 9.9 ewes/ha and 17.7 lambs/ha in the -Grain treatment. The absolute stocking rates in Year 2 were lower than the previous year but the -Grain mob again had $\sim 4 \%$ more ewes and $\sim 9 \%$ more lambs than the + Grain mob. Weaned lambs returned to graze in early December for about 5 weeks before destocking.

\section{Draft for slaughter}

In Year 1 only $3.2 \%$ of + Grain lambs and $6 \%$ of -Grain lambs were drafted for slaughter (32 kg/lamb) at weaning. By destocking $78 \%$ of -Grain lambs and $81 \%$ of +Grain lambs had been drafted and sent for slaughter. In Year 1 the +Grain lamb mob had about $50 \%$ ewe lambs compared with the -Grain group which had about $60 \%$ ewe lambs. Ewe lambs grew 
$\sim 13 \%$ slower than the ram lambs $(r=0.98)$. The higher proportion of ewe lambs in the -Grain group would partly explain the higher stocking rate in the -Grain group at destocking in February (Figure 1). In Year 2 (2014/2015) $26 \%$ of + Grain lambs and 22\% of -Grain lambs were drafted for slaughter at weaning. However, there was a $9 \%$ higher lamb stocking rate in the-Grain treatment group.

\section{Weighted seasonal liveweight gains}

During lactation, the weighted average growth rate for each lamb at foot was $241 \mathrm{~g} / \mathrm{d}$ (Table 1). At no time during lactation did liveweight gains of lambs at foot differ between \pm Grain treatments ( $\mathrm{P}$ values 0.486 to 0.904). The + Grain ewes benefitted from barley grain in early $(13 / 9$ to $3 / 10 / 2013 ; \mathrm{P}<0.05)$ and late $(14 / 11$ to $2 / 12 / 2013, \mathrm{P}<0.05)$ lactation. Post-weaning +Grain lambs grew faster $(3 / 12$ to $16 / 12 / 2013 ; \mathrm{P}<0.01)$ immediately after weaning but grew at similar rates to -Grain weaned lambs in the next two periods. This resulted in comparable weighted liveweight gains for the entire weaned lamb phase (Table 1).

In $2014 / 2015$, ewes gained (18/9 to $22 / 10 / 2014)$ and lost (22/10 to $7 / 11 / 2014)$ similar liveweights ( $\mathrm{g} /$ day per ewe) in the lactation phase, regardless of access to barley. The weighted mean daily growth rate (Table 1) showed +Grain ewes each gained $27.4 \mathrm{~g}$ /day during the lactation phase while -Grain ewes gained $67.9 \mathrm{~g}$ /day before destocking. Each lamb at foot allocated to the + Grain treatment gained $353 \mathrm{~g} /$ day and those without grain supplementation grew at $334 \mathrm{~g} /$ day. Liveweight gains did not differ between the treatments at either measurement period $(\mathrm{P}=0.313$ and $\mathrm{P}=0.010)$. Post-weaning each + Grain

Table 1 Weighted seasonal liveweight gain ( $g /$ day) for ewes and lambs grazing lucerne monocultures with (+Grain) or without (-Grain) access to barley grain supplementation in 2013/2014. Figures are weighted over the grazing period and account for variations in stocking rate and duration of grazing between treatments from the initiation of grazing.

\begin{tabular}{lccc}
\hline 2013/2014 & Treatment & $\begin{array}{c}\text { Ewes } \\
\text { (g/ewe/day) }\end{array}$ & $\begin{array}{c}\text { Lambs } \\
\text { (g/lamb/day) }\end{array}$ \\
\hline Spring (lactation) & +Grain & 13.9 & 241 \\
& -Grain & -16.9 & 240 \\
Summer (post-weaning) & +Grain & - & 199 \\
& -Grain & - & 187 \\
\hline
\end{tabular}

\section{4/2015}

\begin{tabular}{lccc} 
Spring (lactation) & +Grain & 27.4 & 353 \\
& -Grain & 67.9 & 334 \\
Summer (Post-weaning) & +Grain & - & 154 \\
& -Grain & - & 188 \\
\hline
\end{tabular}

lamb grew $154 \pm 9.8 \mathrm{~g} / \mathrm{d}$ which was similar $(\mathrm{P}=0.989)$ to the $188 \pm 9.7 \mathrm{~g}$ /day from -Grain weaned lambs.

\section{Liveweight production $(\mathrm{kg} / \mathrm{ha})$}

In 2013/2014 the +Grain ewes gained $(\mathrm{P}<0.01) 13.0 \pm$ $3.5 \mathrm{~kg} \mathrm{LWt} / \mathrm{ha}$ while -Grain ewes lost $16.4 \pm 3.5 \mathrm{~kg} / \mathrm{ha}$. Barley supplementation had no impact on liveweight production of lambs at foot $(457 \pm 5.8 \mathrm{~kg} \mathrm{LWt} / \mathrm{ha})$ nor on post-weaning liveweight production $(213 \pm 4.0 \mathrm{~kg}$ $\mathrm{LWt} / \mathrm{ha}$ ). Total lamb LWt production was $671 \pm 9.5 \mathrm{~kg}$ $\mathrm{LWt} / \mathrm{ha}$. In Year 2 (2014/2015), ewes produced $14 \pm 2.2$ $\mathrm{kg} \mathrm{LWt} / \mathrm{ha}$ (+Grain) compared $(\mathrm{P}<0.001)$ with $35 \pm 2.2$ $\mathrm{kg} / \mathrm{ha}$ (- Grain) during the lactation phase. The + Grain lambs produced $298 \pm 1.0 \mathrm{~kg} / \mathrm{ha}$ which was $3 \%$ less $(\mathrm{P}<0.001)$ than the $306 \pm 1.0 \mathrm{~kg} \mathrm{LWt} / \mathrm{ha}$ produced from -Grain lambs.

Post-weaning lamb production was $84 \pm 1.6 \mathrm{~kg} \mathrm{LWt} /$ ha from the + Grain treatment compared $(\mathrm{P}<0.001)$ with $102 \pm 1.6 \mathrm{~kg} \mathrm{LWt} / \mathrm{ha}$ from the -Grain treatment. Total lamb LWt production across the lactation and weaned lamb phases was $408 \pm 1.0 \mathrm{~kg} \mathrm{LWt} / \mathrm{ha}$ from the -Grain lambs compared $(\mathrm{P}<0.001)$ with $382 \pm 1.0 \mathrm{~kg} \mathrm{LWt} / \mathrm{ha}$ from the +Grain mob.

\section{Dry matter production and utilisation}

Total accumulated lucerne yield for the grain feeding experiment was $11.8 \pm 0.24 \mathrm{t} / \mathrm{DM} / \mathrm{ha}$ in the wetter Year $1(3 / 9 / 2013$ to $3 / 2 / 2014 ; 153$ d) of which $4.7 \pm$ $0.32 \mathrm{t} \mathrm{DM} / \mathrm{ha}$ was consumed. In the drier 2014/2015, yield totalled $4.6 \pm 0.13 \mathrm{t} \mathrm{DM} / \mathrm{ha}$, of which $2.6 \pm 0.10 \mathrm{t}$ $\mathrm{DM} /$ ha was consumed. This represented yield on offer from the start of the lactation phase (18/9/2014) to destocking (7/1/2015) and represents 91 days grazing due to removal of stock between 7-27/11/2014. There were no differences in pre-grazing DM, post-grazing $\mathrm{DM}$ or DM consumption during either year.

\section{Discussion}

Ewes appeared to be the stock class that ate the grain. Average intakes from lambs post-weaning (46-79 g/ $\mathrm{lamb} / \mathrm{d}$ ) in Year 1 were substantially lower than during lactation $(83 \mathrm{~g} / \mathrm{d})$. Weighted seasonal liveweight production in Year 1 showed lambs at foot grew at 241 $\mathrm{g} / \mathrm{lamb} / \mathrm{d}$ (Table 1) and weaning occurred at 12.5 weeks (88 days) with lucerne stocked at $\sim 11.5$ ewes/ha (Figure 1). The lack of difference in DM yield and DM utilisation in the lactation phase supported the hypothesis that increased ewe liveweight gain during lactation (Table 1) and subsequent liveweight production was a result of barley grain supplementation rather than increased DM intake. Similarly, the lack of difference in liveweight production between \pm Grain treatments is consistent with the DM yield and utilisation data.

It did appear that by the mid-December draft (Figure 1) more lambs were ready to be drafted in the +Grain 
treatment group. However, the ability to attribute this to the barley supplementation was confounded by the lower lamb stocking rate. This resulted from the random allocation of all single bearing ewes to the + Grain mob and a higher proportion of faster growing ram lambs $(50 \%)$ in the +Grain group compared with $40 \%$ in the -Grain mob. The ewe lamb growth rate was about 13\% lower $(r=0.98)$ than ram lamb growth rate regardless of grain supplementation. Singles have previously been shown to gain weight at a faster rate during lactation than twins (Muir et al. 2000).

In Year 2 the overall mean liveweight gain for ewes and lambs over the lactation phase was similar for both \pm Grain treatments. Post-weaning lambs had an apparent grain intake of $24.6 \mathrm{~g} / \mathrm{lamb} /$ day. Grain consumption did not translate into improved liveweight gain by either ewes or lambs. This was lower than average grain consumption post-weaning in Year 1 but this may reflect the change from whole to crushed barley. Previously published literature indicated that processing grain aids digestion by cattle (Campling 1991) but it may have a negative effect on sheep. Processed barley decreases ruminal $\mathrm{pH}$ by about 1 unit whereas whole barley did not (Ørskov et al. 1974). This decrease in $\mathrm{pH}$ was associated with a reduction in cellulolytic bacteria in rumen fluid (Mann \& Ørskov 1975).

Superior liveweight gains per head in Year 2 for both ewes and lambs could be a result of the lower stocking rates (Figure 1; Table 1), and consequently more feed on offer per head. The dams of both treatment groups lost $344 \mathrm{~g}$ /ewe/d from 22/10/2014 to 7/11/2014 (18 d) in Year $2(\mathrm{P}=0.642)$. The +Grain ewes could not access grain during this period. This implies ewes from both treatment groups lost condition to maintain lamb production as feed supply declined in late lactation in the "dry" season. In addition, lambs in the +Grain mob appeared to supplement their feed supply with grain over the same 18 days to mitigate the lack of lucerne feed available. They gained $340 \pm 13.1 \mathrm{~g} / \mathrm{lamb} / \mathrm{d}$ over the same period which was more $(\mathrm{P}<0.01)$ than the 297 $\pm 12.5 \mathrm{~g} / \mathrm{d}$ gained by - Grain lambs. This suggests a positive effect of the grain as a direct source of feed at a time of reduced feed supply. However, this only occurred in late lactation and across the entire lactation phase the effect was less obvious (Table 1).

The weighted seasonal liveweight gains (Table 1) of lambs at foot in Year 2 on both treatments (330-350 $\mathrm{g} / \mathrm{lamb}$ /day) were higher than those expected for twin lambs across New Zealand (Muir et al. 2003; Kerr 2010). This occurred despite water stress on the lucerne which resulted in the pastures being destocked earlier than in an average year (Figure 1). The 3\% higher liveweight production from the -Grain lambs at foot primarily reflected differences in stocking rate (Figure 1). In practice, $8 \mathrm{~kg} \mathrm{LWt} /$ ha lower production from
+Grain lambs is unlikely to be measureable on-farm but does indicate the purchased grain was unnecessary. This also applied to liveweight production in the postweaning phase in Year 2. Grain supplemented lambs produced $18 \%$ less liveweight per hectare compared with the-Grain mob. This difference also reflected the higher liveweight gain per head of weaned lambs in the -Grain mob (188 versus $154 \mathrm{~g} / \mathrm{d}$ ) as both treatments were stocked at the same rate (Figure 1).

There were no differences in DM yield or utilisation in $2014 / 2015$ so the reasons for lower liveweight production from + Grain lambs is unclear, particularly given the slightly higher stocking rate in the -Grain treatment (Figure 1). Theoretically this meant feed allocation per animal would have been slightly lower for the-Grain mob.

The implication is that the substitution rate of grain to pasture was zero (Dixon \& Stockdale 1999) and that ingested grain was a supplement rather than a substitute for lucerne. However, results in Year 2 indicate ingestion of crushed barley grain inhibited the conversion of ingested lucerne forage into animal liveweight. Further, the estimated daily allocation of grain was low at 25$31 \mathrm{~g} / \mathrm{sheep} / \mathrm{d}$ across the lactation and weaned lamb phases. In the weaned lamb phase + Grain lambs averaged $25 \mathrm{~g}$ barley/d. Thus, there was no obvious reason for the lower liveweight gains from +Grain mob. Most published research indicates liveweight production is either unchanged or is increased by grain supplementation (Caton \& Dhuyvetter 1997), so this result was unexpected. However, Sormunen-Cristian (2013) reported lambs fed a grain only diet had lower liveweight at slaughter when fed crushed barley than those fed whole grains. The majority of published research focusses on providing protein supplementation to increase intake and digestibility of low to medium quality forages such as hay or mature grass (Petersen 1987). The grain intake per head was $<50 \mathrm{~g} / \mathrm{d}$ and the animals did not gorge on grain (visual observation) so acidosis seems unlikely, even though crushed grain was fed, as it would have constituted a minor amount of daily feed intake. The lack of a positive response is consistent with Klee et al. (2011) and Wolfe et al. (1980), who also used fresh high quality forage sources and found that grain supplementation did not translate to consistent or repeatable increases in steer liveweight production.

Visual observations showed lambs were attracted to the feed dispenser for shelter/shade rather than as a feed source. This may help explain the poor performance of the +Grain lambs post-weaning in Year 2. The congregation for shade attracted flies and seven weaned lambs from the + Grain mob were treated for flystrike compared with two from the -Grain mob. Further, $20 \%$ of the + Grain weaned lambs required dagging 
compared with only $10 \%$ of the lambs allocated to the -Grain mob in 2014/2015.

\section{Conclusions}

- Barley grain supplementation had no effect on liveweight per hectare by lambs pre- or post-grazing in Year 1. A total of $782 \pm 11.5 \mathrm{~kg}$ lamb LWt/ha was produced.

- In Year 2, liveweight production from +Grain lambs was 3\% lower during lactation and $18 \%$ lower in the weaned lamb phase compared to the-Grain lambs.

- Dry matter yields and the quantity of DM consumed were similar for both the \pm Grain mobs. This indicated barley grain was not substituting for ingestion of fresh lucerne forage.

- These findings, over 2 years indicate no basis for grain feeding to sheep grazing fresh lucerne.

\section{ACKNOWLEDGEMENTS}

The Dryland Pastures Research Team received funding for this experiment from Beef + Lamb New Zealand (Project 13LU01). The experiment was superimposed on the 'MaxLucerne' grazing experiment which formed part of Phase II of the Pastoral 21 Programme, funded by the Ministry for Business, Innovation \& Employment, DairyNZ, Beef + Lamb New Zealand and Fonterra.

\section{REFERENCES}

Advantage Feeders Ltd. 2013. Advantage Feeders Home page. Accessed: 19/08/2016. http://www. advantagefeeders.com.au/.

Broderick, G. 2001. Maximizing utilization of alfalfa protein: The example of the lactating dairy cow. Quality in lucerne and medics for animal production. Options Méditerranéennes : Série A. Séminaires Méditerranéens 45: 183-192.

Campling, R.C. 1991. Processing cereal grains for cattle - a review. Livestock Production Science 28: 223-234.

Cannas, A. 2004. Feeding of lactating ewes. pp. 79108. In: Dairy sheep nutrition. Ed. Pulina, G. CABI Publishing, Wallingford.

Cannas, A.; Van Soest, P. 2000. Simple allometric models to predict rumen feed passage. pp. 49-62. In: Modelling nutrient utilization in farm animals. Eds. McNamara, J.P.; France, J.; Beever, D.E. CAB International, Wallingford, UK.

Caton, J.S.; Dhuyvetter, D.V. 1997. Influence of energy supplementation on grazing ruminants: requirements and responses. Journal of Animal Science 75: 533542.

Dixon, R.M.; Stockdale, C.R. 1999. Associative effects between forages and grains: consequences for feed utilisation. Australian Journal of Agricultural Research 50: 757-773.
Doyle, P.T.; Dove, H.; Freer, M.; Hart, F.J.; Dixon, R.M.; Egan, A.R. 1988. Effects of a concentrate supplement on the intake and digestion of a lowquality forage by lambs. The Journal of Agricultural Science 111: 503-511.

Karnezos, T.P.; Matches, A.G.; Preston, R.L.; Brown, C.P. 1994. Corn supplementation of lambs grazing alfalfa. Journal of Animal Science 72: 783-789.

Kerr, P. 2010. 400 plus - a guide to improved lamb growth. New Zealand Sheep Council in association with WoolPro and Meat New Zealand.

Klee, G.; Mendoza, N.; Chavarria, J. 2011. Production and meat fatty acids profile of Hereford steers fed on pasture with and without oat grain supplement. Chile, VIII Region. Ciencia E Investigacion Agraria 38: 331-338.

Mann, S.O.; Ørskov, E.R. 1975. The effect of feeding whole or pelleted barley to lambs on their rumen bacterial populations and $\mathrm{pH}$. Proceedings of the Nutrition Society 34: 63-64.

Muir, P.D.; Smith, N.N.; Lane, J.C. 2003. Maximising lamb growth rate - just what is possible in a high performance system. Proceedings of the New Zealand Grassland Association 65: 61-63.

Ørskov, E.R.; Fraser, C.; Gordon, J.G. 1974. Effect of processing of cereals on rumen fermentation, digestibility, rumination time, and firmness of subcutaneous fat in lambs. British Journal of Nutrition 32: 59-69.

Petersen, M.K. 1987. Nitrogen supplementation of grazing livestock. pp. 115-121. In: Proceedings of the $1^{\text {st }}$ Grazing Livestock Nutrition Conference. Eds. Judkins, M.B.; Clanton, D.C.; Petersen, M.K.; Wallace, J.D.

Pollock, K.M. 2012. Climate. pp. 23-27. In: Ashley Dene Lincoln University Farm: the first 100 years. Eds. Lucas, R.J.; Gow, N.; Nichol, A. Lincoln University, Christchurch.

Schroeder, G.F.; Titgemeyer, E.C. 2008. Interaction between protein and energy supply on protein utilization in growing cattle: A review. Livestock Science 114: 1-10.

Sormunen-Cristian, R. 2013. Effect of barley and oats on feed intake, live weight gain and some carcass characteristics of fattening lambs. Small Ruminant Research 109: 22-27.

Van Soest, P.J. 1994. Nutritional ecology of the ruminant $\left(2^{\text {nd }} E d\right.$.). Cornell University Press, Ithaca and London. 528 pp.

Wolfe, E.C.; Fitzgerald, R.D.; Hall, D.G.; Southwood, O.R. 1980. Beef-production from lucerne and subterranean clover pastures. The effects of pasture, stocking rate and supplementary feeding. Australian Journal of Experimental Agriculture 20: 678-687. 
